\title{
Impact of Livestock Farming on Human Onchocerciasis in Adamawa and North Regions Cameroon
}

\author{
Amadou Sanda $^{1 *}$, Dieudonne Ndjonka ${ }^{1}$ and Eva Liebau ${ }^{2}$ \\ ${ }^{1}$ Department of Biological Science, Faculty of Science, University of Ngaoundere, Cameroon \\ ${ }^{2}$ Institute for Zoophysiology, Schlossplatzr, Germany \\ "Corresponding author: Amadou Sanda, Department of Science Biological, University of Ngaoundere, Cameroon, Tel: +237661982704; E-mail: \\ amadousanda33@yahoo.fr
}

Received date: July 19, 2018; Accepted date: September 09, 2018; Published date: September 15, 2018

Copyright: (c) 2018 Sanda A, et al. This is an open-access article distributed under the terms of the Creative Commons Attribution License; which permits unrestricted use; distribution; and reproduction in any medium; provided the original author and source are credited.

\begin{abstract}
Background: Onchocerciasis or "river blindness" is currently a major cause of blindness in the world. The use of Ivermectin by the high risk population showed its limits. In these regions, cattle raising is the main occupation and human onchocerciasis is reduced since the high density of cattle stocking protects by zooprophylaxis and cross immunization. This work was carried out in order to know if cattle protect humans against human onchocerciasis. To achieve this goal, two high densities of cattle stocking and onchocerciasis zones were selected: Wakwa and Touboro, two zones of Cameroon located on the Vina River.
\end{abstract}

Methods: Blackflies were collected in each zone and dissected thereafter. Skin biopsies were carried out on volunteers. Infested with Onchocerca blackflies were the subject of detailed accounts and biopsies for microfilariae.

Results: Dissections showed $83.87 \%$ of infected blackflies with O. ochengi in Wakwa and $82.5 \%$ in Touboro. Moreover, $17.5 \%$ of parasitized blackflies were parous of $O$. volvulus in Touboro against $16.13 \%$ in Wakwa. Biopsy results displayed that Wakwa recorded a rate of $2 \%$, while Touboro $4 \%$ onchocerciasis microfilariae.

Conclusions: These results show that the cattle raising influence the transmission of onchocerciasis in humans.

Keywords: Onchocerciasis; Blackflies; Biopsy; Microfilariae

\section{Introduction}

Simulium damnosum is a complex group of over 40 sibling species of blackfly distributed throughout the Sub-Saharan Africa and the Arabian Peninsula [1]. Blackflies are responsible for more than $90 \%$ of onchocerciasis cases worldwide and $95 \%$ of cases in Africa [1]. About 54 species of Simulium have been reported to bite man, transmitting onchocerciasis [1]. In Cameroon, the cytospecies and cytotypes reliably recorded include $S$. damnosum s.s.; Nile form, $S$. damnosum s.s.; Volta form, $S$. sirbanum s.l., $S$. squamosum A , $S$. squamosum B, $S$. squamosum $\mathrm{C}, S$. squamosum $\mathrm{D}$ and $S$. mengens [2]. Onchocerciasis is a parasitic disease caused by a worm of Onchocerca genus, parasitic nematode hoofed mammals $[3,4]$ whose vectors are the blackflies. In humans, Onchocerca volvulus is primarily responsible for this disease [3]. Onchocerciasis is also called "river blindness" due to the fact that it is contacted in the vicinity of rapid streams [5]. This disease attacks not only the skin like nodule, hanging groin (6.5 million suffer from severe skin diseases), but also results in the permanent loss of sight. In a recent survey of Schwartz et al. [6] in the Central African Republic, onchocerciasis was found responsible for $73.1 \%$ cases of blindness in the population [7].

Onchocerciasis is currently a major cause of blindness in the world. The eradication of the disease is a great challenge for modern public health [7]. O. volvulus not only causes chorio-retinitis but also produces severe keratitis. Besides, it is developed as a result of an inflammatory response to dead microfilariae which are degenerated thereafter into the corneal stroma [7]. The infestation may clinically present palpable subcutaneous nodules. The female worms produce thousands of microfilariae that cross embryonic fibrous tissue and invade the epidermis [8]. O. volvulus embryonic forms migrate through the skin and causes severe itching, disfiguration, and ocular lesions [9]. Keratitis and blindness can be the result of heavy parasite loads in the human host over time. The parasite is encapsulated in fibrous tissue [9]. The female adult worm measures $30 \mathrm{~cm}$ to $80 \mathrm{~cm}$ long while the male measures $3 \mathrm{~cm}$ to $5 \mathrm{~cm}$ [8]. The female produces microfilariae whose length is between $250 \mu \mathrm{m}$ to $300 \mu \mathrm{m}$.

The number of people infected by $O$. volvulus is estimated at 17.7 million through the 34 countries worldwide. Over $99 \%$ are found in Inter-Tropical Africa, Central and South America and the Middle East [4]. It is considered that $270,000-360,000$ people are blind due to onchocerciasis [10]. In addition, about 500,000 other people suffer from severe visual disability associated with onchocerciasis [11]. We believe that over 860,000 people are currently having ocular involvement and are likely to become totally blind if no treatment has been initiated. According to Boussinesq [11], onchocerciasis is the fourth leading cause of blindness worldwide after cataract (16 million people), trachoma (5.9 million), and various forms of glaucoma (5.1 million) [11]. People affected by the disease lose $15 \%$ of their annual revenues for treatment. In addition, $30 \%$ of uncultivated land, school non-attendance of children and exacerbation of rural poverty are linked to onchocerciasis [11]. 
In 1983, 1.2 million Cameroonians' blind, have been identified by United Nation demographic report, 5,000,000 infected and 30,000 blinds [2]. Currently there are 32,000 blinds due to onchocerciasis. Facing these increasing and alarming victims over years, appropriates' measures shall have taken to predict the risk abandonment land which was the case in West Africa before independence [7].

Different drugs have been administered but showed their limits. For example, Microfilaricid (Diethylcarbamazin, Ivermectin and Modexin) cannot kill adult worm, Macrofilaricid (Suramin, Doxycyclin, Rifampicin, Azithromycin, Fosfomycin) cannot kill microfilaria. In addition, elders, pregnant women and children cannot use them because of their side effects. Beside this, Simulium damnosum is the same vector transmitting Onchocerca volvulus, $O$. ochengi, $O$. gutturosa, $O$. armilata, $O$. dukei and $O$. bovis cattle parasites in Cameroon

This work investigated if cattle raising is limiting factor for spreading human onchocerciasis. To assess the relevance of our research, blackflies and bloodless biopsies were submitted for parasite evaluation.

\section{Methods and Material}

\section{Description of the study site}

In the Adamawa Region: The Adamawa Region of Cameroon is located in Central Africa between the $6^{\text {th }}$ and $8^{\text {th }}$ degree of north latitude and the $10^{\text {th }}-16^{\text {th }}$ degree east longitude [12]. It covers an area of about $62,000 \mathrm{~km}^{2}$, with altitudes of $900 \mathrm{~m}$ to $1,500 \mathrm{~m} \mathrm{[12].} \mathrm{It} \mathrm{is}$ characterized by two seasons: a rainy season and a dry season. The average annually rainfall, temperature and humidity are about 1,500 $\mathrm{mm}, 22^{\circ} \mathrm{C}$ and $70 \%$ respectively.

The location of IRAD-Wackwa is as follows: $7^{\circ} 12.035^{\prime} \mathrm{N}$ of longitude, $13^{\circ} 34.933^{\prime} \mathrm{E}$ of latitude and $1032 \mathrm{~m}$ of altitude. That of Mandjiri as follows: $7^{\circ} 13.280^{\prime} \mathrm{N}$ of longitude, $13^{\circ} 35.637^{\prime} \mathrm{E}$ of latitude and $1065 \mathrm{~m}$ of altitude. Adamawa with its temperate climate has a permanent pasture [13]. The main activity is cattle raising with reportedly more than 5,600,000 heads estimated in 2005 [14] (Figure 1). Cattle production in the region represents about $86.6 \%$ of domestic livestock population and more than $28 \%$ of the national cattle head estimated at about 10 million [12]. The flocks do not go on transhumance in the dry season. Watering knows no major obstacles. The existence of grasslands is another parameter that promotes the raising of cattle.

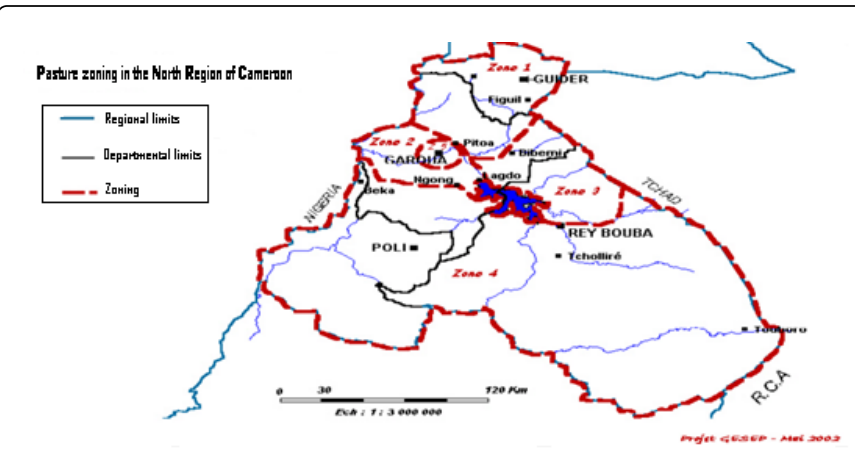

Figure 1: Pasture zoning in the north region of Cameroon [14].
In the North Region: The North region extends between $8^{\circ}$ and $10^{\circ} \mathrm{N}$ latitude $12^{\circ}$ and $16^{\circ} \mathrm{E}$. The climate is of Sudanese type with six months of rainy season and six months of dry season, and an average temperature of $35^{\circ} \mathrm{C}$. Agriculture and livestock account for $90 \%$ of the population, north Province, with 4 million of bovine in 2005 [14]. Touboro belongs to the Sudano-Sahelian zone whose vegetation is of shrubs and herbs. Geographical features are: longitude: $7^{\circ} 46^{\prime} 60^{\prime \prime} \mathrm{N}$, latitude: $15^{\circ} 22^{\prime} 0$ "E. It is located at an altitude of 531 meters above the sea. Cattle increasing are an important for livestock in this area. Lagaye is a village located $10 \mathrm{~km}$ from the city of Touboro on the road to Mbaïboum.

\section{Skin snip collection}

Biopsy as part of this study was a skin snip collected for search of microfilariae responsible of onchocerciasis. 50 people in each area were subjected for biopsy and biopsies were performed at the iliac crest, scapula and calf of each volunteer person (Table 1).

\begin{tabular}{|c|c|c|c|}
\hline Localities & $\begin{array}{l}\text { Number } \\
\text { volunteers }\end{array}$ & $\begin{array}{l}\% \text { of } \\
\text { blindness }\end{array}$ & $\begin{array}{l}\% \text { of } \\
\text { onchocerciasis }\end{array}$ \\
\hline Mandjiri & 50 & $2 \%$ & $2 \%$ \\
\hline $\begin{array}{l}\text { Touboro- } \\
\text { Lagaye }\end{array}$ & 50 & $4 \%$ & $4 \%$ \\
\hline Wakwa-IRAD & 50 & $0 \%$ & $0 \%$ \\
\hline
\end{tabular}

Table 1: Rate of blindness and onchocerciasis in different localities.

Samples were collected with sterilized razor blade per person. Small pieces of skin about $2 \mathrm{~mm}$ to $3 \mathrm{~mm}$ of diameter were collected. The sampling site was previously disinfected with alcohol swab. The skin fragment was left for 15 minutes in $5 \%$ dextrose for microfilariae to leave the skin. Thereafter, $2 \mathrm{ml}$ of $10 \%$ formalin was added and we obtain $4 \%$ of solution $(\mathrm{w} / \mathrm{v})$. Bottles were hand-shaken for proper mixture of the contents. Then, the bottles were closed with their screw caps and brought back to the laboratory for examination. The contents of each vial was labelled per volunteer then transferred in dry tubes. Tubes were grouped in lots of 10 and placed in the cooler, which had a capacity of 70 tubes. Tubes were centrifuged for 3 minutes at 10,000 rpm. The supernatant from each conical tube was put back in the bottle according to the serial number of samples. The pellet of each tube was removed and spread on object slide without thin slide. All slides were observed at $100 \mathrm{X}$ under microscope. Dead microfilariae were well observed by staining with an angular curved tail that is their characteristic and accounted (Figure 2).

\section{Capture and storage of blackflies}

Blackflies were aspired during their meal (Figure 2) and were collected in a plastic tube EDTA K3 for proper conservation and to avoid they get dried.

\section{Identification of the blackfly}

Blackfly was deposited on a slide which carried a drop of saline solution. The observation showed a foreleg wearing thin bristles combs, while the hind leg has a white spot band occupying three quarters of basi-tarsus. The abdomen bears silvery and shiny scales. This identification allowed us to avoid the confusion with other blackflies. Then, the dissection was performed by using two 
Citation: Sanda A, Yinyang Danga SP, Youmbi N (2018) Impact of Livestock Farming on Human Onchocerciasis in Adamawa and North Regions Cameroon. J Trop Dis 6: 278. doi:10.4172/2329-891X.1000278

Page 3 of 8

entomological needles and dissecting forceps. The forceps were used to pick up a blackfly from the samples and deposit it on the slide. A needle kept the blackfly while another one was used to remove the first abdominal segments as well as the various internal organs (stomach and gut, malpighian tubes, ovaries and fat) as described by $[15,16]$. Abdomen, thorax and head were separately dissected and examined. Larvae of Onchocerca were counted.

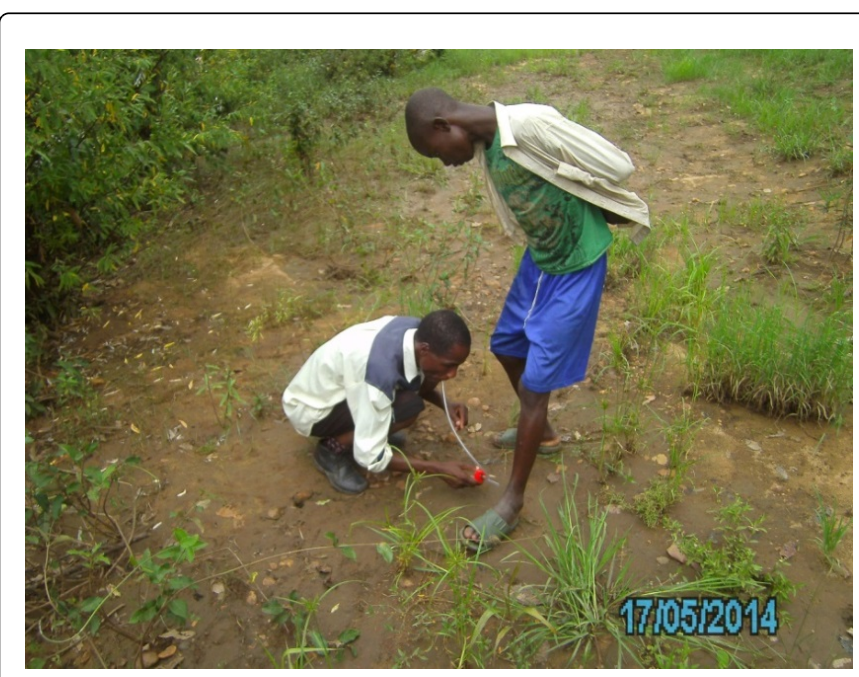

Figure 2: Capture of blackflies near the Vina River Touboro (Vokna).

Internal organs showed the differences between nulliparous blackfly and parous blackfly, under a binocular microscope by highlighting the follicular relics in the ovaries, the presence of residual eggs indicating a previous nesting female, the presence of abundant abdominal fat, and presence of residual blood in the stomach indicating a previous blood meal. Overall malpighian tubes in nulliparous were opaque, thick and swollen [16].

The nulliparous ovaries were clear, slightly larger and more spherical, stretched very slowly before breaking abruptly. However, the parous had clear Malpighian tube under transmitted light, and ovaries stretched along their full length and tore slowly. The best examination was done in saline, $45 \% \mathrm{NaCl}$ under a stereo microscope with $50 \mathrm{X}$ magnification.

The thorax muscles and the head were separately lacerated where the L1 and L2 and L3 larvae were located, respectively. The difference between $O$. volvulus and $O$. ochengi was observed in the size of L3 larvae; L3 for $O$. volvulus measured 440 microns to 700 microns and that of $O$. ochengi, 750 microns to 850 microns. This method was scrutinized for search of $O$. volvulus and $O$. ochengi larvae. The number and the developmental stages were established to determine the infestation rate and the parasitic loads of female Simulium damnosum complex.

Ethical approval: After sensitizing the community, many volunteers accepted to know their dermal microfilaria.

\section{Results}

\section{Captured and dissected blackflies in Mandjiri}

During three months, 594 blackflies were captured and 525 dissected out of which 346 were parous (blackflies those have laid eggs at least one time), 31 were infested rating $8.95 \%$ of infestation. 26 blackflies were infested by $O$. ochengi and five blackflies were infected by $O$. volvulus (Tables 2 and 3).

\begin{tabular}{|c|c|c|c|c|}
\hline & August & October & November & Total \\
\hline Blackflies captured & 262 & 116 & 216 & 594 \\
\hline Blackflies dissected & 193 & 116 & 216 & 525 \\
\hline Parous & 88 & 99 & 159 & 346 \\
\hline Nulliparous females & 105 & 17 & 57 & 179 \\
\hline $\begin{array}{l}\text { Parous infectious (L1 / L2 / } \\
\text { L3) }\end{array}$ & 7 & 5 & 19 & 31 \\
\hline $\begin{array}{l}\text { Number of parasites } \\
\text { volvulus }+O \text {. ochengui) }\end{array}$ & 20 & 7 & 53 & 80 \\
\hline Parous infectious (with L3) & 4 & 3 & 12 & 19 \\
\hline Rate Parous infectious & $7,95 \%$ & $5,05 \%$ & $11,94 \%$ & $8,95 \%$ \\
\hline Rate Infected parous & $4,54 \%$ & $3,03 \%$ & $7,75 \%$ & $5,49 \%$ \\
\hline $\begin{array}{l}\text { Parous infectious (Number of } \\
\text { O. volvulus) }\end{array}$ & $4(11)$ & $0(0)$ & $1(4)$ & $5(15)$ \\
\hline $\begin{array}{l}\text { Parous infectious(Number of } \\
\text { O. ochengi) }\end{array}$ & $3(9)$ & $5(7)$ & $18(49)$ & $26(65)$ \\
\hline \multicolumn{5}{|c|}{$\begin{array}{l}\text { "Parous infectious (Number of } \mathrm{O} \text {. volvulus): } 4 \text { (11): } 4 \text { means parous infectious } \\
\text { and } 11 \text { O. volvulus }\end{array}$} \\
\hline \multicolumn{5}{|c|}{$\begin{array}{l}\text { “Parous infectious (Number of } O \text {. ochengi): } 3 \text { (9) means } 3 \text { parous infectious and } \\
9 \text { O. ochengi. }\end{array}$} \\
\hline
\end{tabular}

Table 2: Results of the dissection of blackfly Mandjiri.

\begin{tabular}{|l|l|l|l|l|l|l|}
\hline & $\begin{array}{l}\text { Captured } \\
\text { blackflies }\end{array}$ & $\begin{array}{l}\text { Dissect } \\
\text { ed } \\
\text { blackflie } \\
\text { s }\end{array}$ & $\begin{array}{l}\text { Parous } \\
\text { infectio } \\
\text { us }\end{array}$ & $\begin{array}{l}\text { Nulliparo } \\
\text { us } \\
\text { Non } \\
\text { infectious }\end{array}$ & $\begin{array}{l}\text { Infecti } \\
\text { ous } \\
\text { parous }\end{array}$ & $\begin{array}{l}\text { Rate of } \\
\text { infectio } \\
\text { us } \\
\text { parous }\end{array}$ \\
\hline August & 262 & 193 & 88 & 105 & 7 & 7.95 \\
\hline October & 116 & 116 & 99 & 17 & 5 & 5.05 \\
\hline $\begin{array}{l}\text { Novembe } \\
\text { r }\end{array}$ & 216 & 216 & 159 & 57 & 19 & 11.94 \\
\hline Total & 594 & 525 & 346 & 179 & 31 & 8.95 \\
\hline
\end{tabular}

Table 3: Results of the dissection of blackfly Mandjiri.

\section{Captured and dissected blackflies in Touboro}

During five months, 544 blackflies captured, 544 dissected, 399 blackflies were parous, and 40 were infested rating 10,02\% infestation. 33 blackflies infested by $O$. ochengi rating $8,27 \%$, seven blackflies were infected by $O$. volvulus giving a rate of $1.75 \%$ (Tables 4,5 and 6). 
Citation: Sanda A, Yinyang Danga SP, Youmbi N (2018) Impact of Livestock Farming on Human Onchocerciasis in Adamawa and North Regions

Page 4 of 8

\begin{tabular}{|c|c|c|c|c|c|c|}
\hline & August & $\begin{array}{l}\text { Septembe } \\
r\end{array}$ & $\begin{array}{l}\text { Octobe } \\
r\end{array}$ & $\begin{array}{l}\text { Novem } \\
\text { ber }\end{array}$ & $\begin{array}{l}\text { Decemb } \\
\text { er }\end{array}$ & Total \\
\hline $\begin{array}{l}\text { Blackflies } \\
\text { (females) } \\
\text { captured }\end{array}$ & 57 & 191 & 111 & 72 & 113 & 544 \\
\hline $\begin{array}{l}\text { Females } \\
\text { dissected }\end{array}$ & 57 & 191 & 111 & 72 & 113 & 544 \\
\hline Parous & 44 & 157 & 90 & 35 & 73 & 399 \\
\hline nulliparous & 13 & 34 & 21 & 37 & 40 & 145 \\
\hline $\begin{array}{l}\text { Infected parous } \\
\text { (L1 / L2 / L3) }\end{array}$ & 3 & 11 & 9 & 6 & 11 & 40 \\
\hline $\begin{array}{l}\text { Nber parasites } \\
\text { (O. volvulus }+O \text {. } \\
\text { ochengui) }\end{array}$ & 5 & 20 & 10 & 9 & 23 & 65 \\
\hline $\begin{array}{l}\text { Parous } \\
\text { infectious (with } \\
\text { L3) }\end{array}$ & 2 & 5 & 7 & 4 & 6 & 24 \\
\hline $\begin{array}{l}\text { Rates of } \\
\text { infectious parous }\end{array}$ & $6.81 \%$ & $7,00 \%$ & $10.00 \%$ & $17.14 \%$ & $15.06 \%$ & $10.0 \%$ \\
\hline $\begin{array}{l}\text { Rate Infected } \\
\text { parous }\end{array}$ & $5.54 \%$ & $3.18 \%$ & $7.77 \%$ & $11.42 \%$ & $8.21 \%$ & $6.01 \%$ \\
\hline $\begin{array}{l}\text { Parous } \\
\text { infectious } \\
\text { (Number of } 0 .^{\text {volvulus) }}\end{array}$ & $0(0)$ & $3(6)$ & $1(2)$ & $1(2)$ & $2(3)$ & $7(13)$ \\
\hline $\begin{array}{l}\text { Parous } \\
\text { infectious } \\
\text { (Number of } 0 . \\
\text { ochengi) }\end{array}$ & $3(5)$ & $8(14)$ & $8(8)$ & $5(7)$ & $9(20)$ & $33(5)$ \\
\hline
\end{tabular}

*Parous infectious (Number of O. volvulus.): 4 (11) 4 means parous infectious and 11 O. volvulus

${ }^{* *}$ Parous infectious (Number of $O$ ochengi.): 3 (9) means 3 parous infectious and 9 O. ochengi

Table 4: Results of the dissection blackflly Touboro.

\begin{tabular}{|l|l|l|l|l|}
\hline & Parasites & $\begin{array}{l}\text { *Parous non } \\
\text { infectious }\end{array}$ & $\begin{array}{l}\text { Parous } \\
\text { infected }\end{array}$ & $\begin{array}{l}\text { Total } \\
\text { parous }\end{array}$ \\
\hline August & $(0 ; 5)=5$ & $\mathbf{4 1}(\mathbf{4 4 - 3 )}$ & 3 & 44 \\
\hline September & $(6 ; 14)=20$ & $\mathbf{1 4 6}(\mathbf{1 5 7 - 1 1 )}$ & 11 & 157 \\
\hline October & $(2 ; 8)=10$ & $\mathbf{8 1}(\mathbf{9 0 - 9 )}$ & 9 & 90 \\
\hline November & $(2 ; 7)=9$ & $\mathbf{2 9 ( 3 5 - 6 )}$ & 6 & 35 \\
\hline December & $(3 ; 20)=32$ & $\mathbf{6 2 ( 7 3 - 1 1 )}$ & 11 & 77 \\
\hline Total & $(13 ; 54)=67$ & $\mathbf{3 5 9 ( 3 9 9 - 4 0 )}$ & 40 & 399 \\
\hline
\end{tabular}

Parous non-infectious comes from the difference between parous and parous infected.

Table 5: Results of the dissection of blackfly Touboro.

\begin{tabular}{|l|l|l|l|l|l|l|}
\hline & $\begin{array}{l}\text { Capture } \\
\text { d } \\
\text { blackflie } \\
\text { s }\end{array}$ & $\begin{array}{l}\text { Dissect } \\
\text { ed } \\
\text { blackflie } \\
\text { s }\end{array}$ & $\begin{array}{l}\text { Parous } \\
\text { infecte } \\
\text { d }\end{array}$ & $\begin{array}{l}\text { Nulliparou } \\
\text { s non } \\
\text { infected }\end{array}$ & $\begin{array}{l}\text { Infectiou } \\
\text { s }\end{array}$ & $\begin{array}{l}\text { Rate of } \\
\text { infectio } \\
\text { us } \\
\text { parous }\end{array}$ \\
\hline
\end{tabular}

\begin{tabular}{|l|l|l|l|l|l|l|}
\hline August & 57 & 57 & 3 & 13 & 2 & 14.29 \\
\hline $\begin{array}{l}\text { Septemb } \\
\text { er }\end{array}$ & 191 & 191 & 11 & 34 & 5 & 3.18 \\
\hline $\begin{array}{l}\text { Octombe } \\
\mathbf{r}\end{array}$ & 111 & 111 & 9 & 21 & 7 & 7.78 \\
\hline $\begin{array}{l}\text { Novembe } \\
\mathbf{r}\end{array}$ & 72 & 72 & 6 & 37 & 4 & 11.43 \\
\hline $\begin{array}{l}\text { Decembe } \\
\mathbf{r}\end{array}$ & 113 & 133 & 11 & 40 & 6 & 14.29 \\
\hline Total & 544 & 544 & 40 & 145 & 24 & 3.18 \\
\hline
\end{tabular}

Table 6: Results of the dissection blackfly Touboro.

NB: Variation of dissected blackflies and Onchocerca volvulus for Wakwa and Touboro are according the dissected blackflies, not $O$.volvulus and $O$. onchengi founded same time in the blackfies collected.

\section{Discussion}

Many studies on onchocerciasis were conducted in Cameroon. This work is the first to be realized. We arbitrarily selected a quota of 200 blackflies dissecting per month. The parous blackflies and infested increasing in the end of the rainy season demonstrated by the Figures 3 and 5.

This analysis showed that November and December are dangerous. Exposed persons should protect themselves against nuisance and biting blackflies. The evolution of parous has been increasing in the two places (Figures 5 and 6).

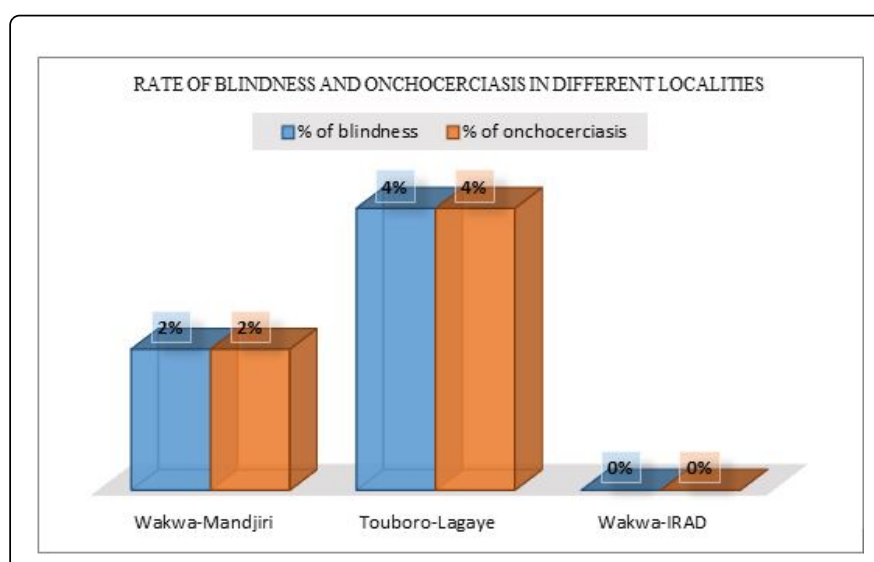

Figure 3: Results of biopsies. 


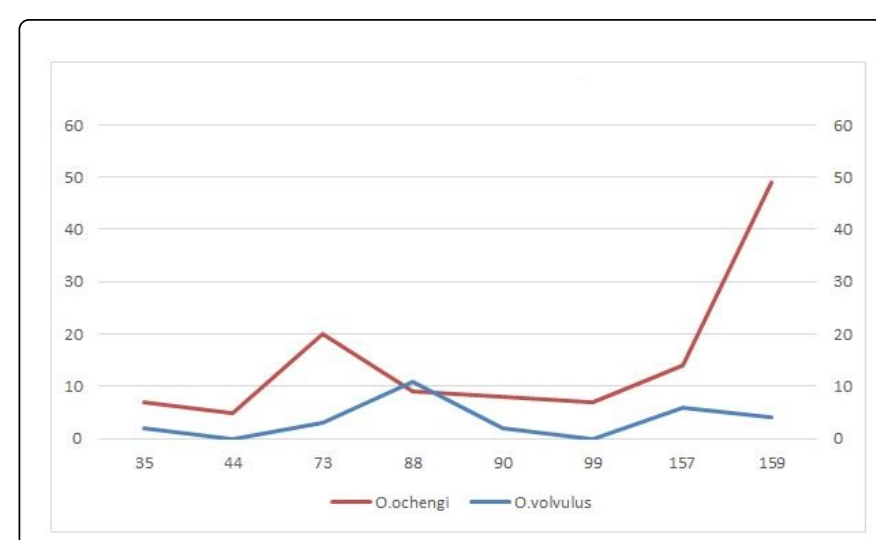

Figure 4: Trendline between $O$. volvulus and $O$. ochengi.

We noted that there's more to parous Wakwa that Touboro. This abundance of parous can be explained by the abundance of livestock (females are blood-sucking blackflies) which corroborate with Martinez who conducte his study about influencing the abundance of Culicoides in avian nets. Infestation of $O$. volvulus to Touboro began in November.

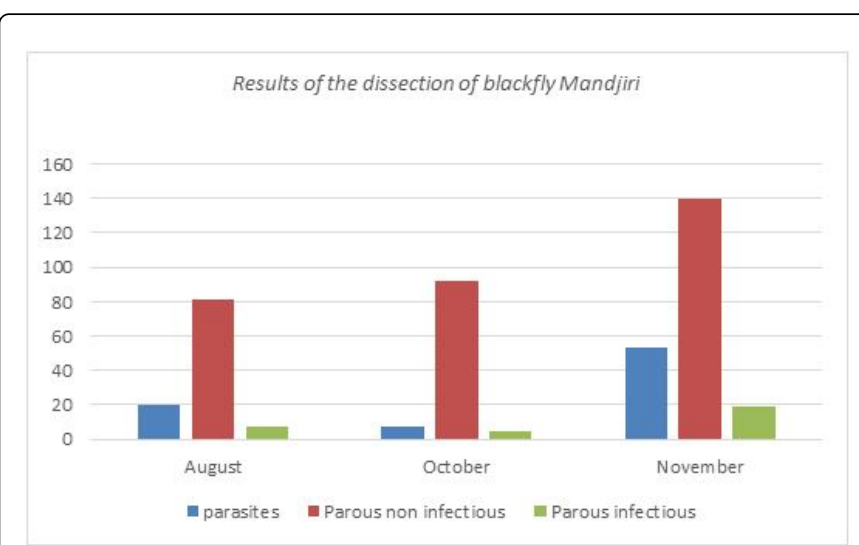

Figure 5: Distribution of parasites in the capture period.

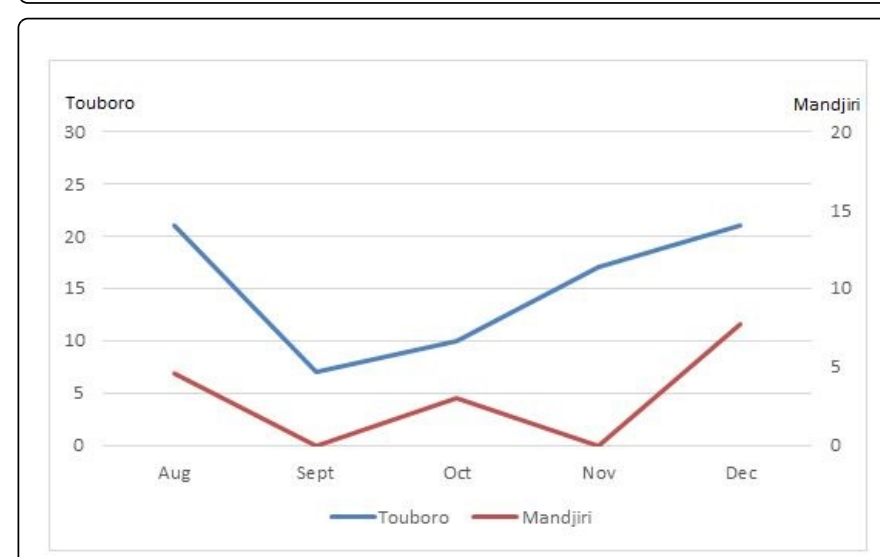

Figure 6: Evolution of the rate of parous infected in the period.
Wakwa site for a total of 346 parous dissected. 31 were parasitized with parous $8.95 \%$ infestation Onchocerca. 26 were $O$. ochengi representative $26 / 31=83.87 \%$. For all pares dissected $26 / 346=7.51 \%$ represented the infestation rate of O.ochengi. For $\mathrm{df}=3$. The value of $\mathrm{x}^{2}$ $5 \%$ was $7.81 \%$. The value found was less than $7.51 \%$ to $7.81 \%$. We can conclude that this result is significant. The IRAD capture point Wakwa recorded a percentage of $100 \%$ O. ochengi. Mandjiri the capture point for a total of 258 dissected. 5 females were parasitized giving a rate of $1.94 \%$ O volvulus and $98.06 \%$ representative O.ochengi. Of the 31 parous parasitized, $5 / 31=16.13 \%$ were parasitized by $O$. volvulus compared to all parous dissected $5 / 346=1.45 \%$ of infestation $O$. volvulus. With $\mathrm{df}=3.5 \%$ was $7.81 \%$. The value found $(1.45 \%)$ was very lower than this threshold value. This result is significant. WHO recommends 01 parous for 2000 blackflies dissected to expect disposal in an area [17]. The onchocerciasis transmission is active Mandjiri.

Skin snips were taken on 50 volunteers in Mandjiri. Only one microfilaria was recorded on one slide representing $2 \%$ of collected samples. In Lagaye (Touboro), two slides revealed one microfilaria each, rating 4\%. In Wakwa-Mandjiri, one case of blindness was registered whereas Lagaye recorded two cases of blindness and three cases of onchocerciasis nodules among the 50 volunteers.

The results of the biopsies revealed microfilaria one $O$. volvulus found in a child of 6 years. One blindness case was found in a man of 70 years native of Mandjiri.

We can say that this point of capture is the most dangerous because it is the location of release of $O$. volvulus. This study was conducted one month after the distribution of Mectizan (ivermectin) by the program against onchocerciasis of the Regional Delegation of Adamawa. Probably this distribution had an impact on the lethality of microfilariae because most skin biopsies were negative.

Lagaye-Touboro for a total of 399 parous dissected. 40 were parasitized with parous $10.03 \%$ infestation by Onchocerca (Table7).

\begin{tabular}{|l|l|l|}
\hline & Touboro & Mandjiri \\
\hline August & 21 & 4.54 \\
\hline September & 7 & No capture \\
\hline October & 10 & 3.03 \\
\hline November & 17 & No capture \\
\hline December & 21 & 7.75 \\
\hline Total & 7 & \\
\hline
\end{tabular}

Table 7: Rate of infected parous (\%).

These pares parasitized; 33 were infested with $O$. ochengi representative $33 / 40=82.5 \%$. For all pares dissected $33 / 399=8.27 \%$ represented the infestation rate of $O$.ochengi. With $\mathrm{df}=5$. the $\mathrm{x}^{2} 5 \%$ was $11.07 \%$ the value found was less than $8.27 \%$ at $5 \%$. This result was significant. Zoophilia blackfly threatening more livestock than humans. The number of cattle dilutes the aggressiveness of blackfkies. Of the 399 black flies captured $(7 / 399=1.75 \%)$ of dissected blackflies were infested by $O$. volvulus. The $\mathrm{x}^{2} 5 \%, \mathrm{df}=5 \%$ was $11.07 \%$.

The infestation rate of $O$. volvulus (1.45\%) in Mandjiri-Adamawa was less than $1.75 \%$ in Lagaye-Touboro. This showed that the blackflies in Touboro were more infested than those of Wakwa thus livestock Touboro had not diluted enough aggressiveness of blackflies [18]. 
Citation: Sanda A, Yinyang Danga SP, Youmbi N (2018) Impact of Livestock Farming on Human Onchocerciasis in Adamawa and North Regions Cameroon. J Trop Dis 6: 278. doi:10.4172/2329-891X.1000278

Page 6 of 8

7 blackflies were parasitized by $O$. volvulus i.e. $7 / 40=17.5 \%$ of the 40 parous parasitized. These results are significant. In addition, 3 persons with cataracts caused by microfilariae and 4 people bore onchocerciasis nodules on 50 examinees. $O$. volvulus rate of $1.45 \%$ was observed in Mandjiri-Adamawa which was less than $1.75 \%$ in LagayeTouboro (Figures 7, 8, 9 and 10).

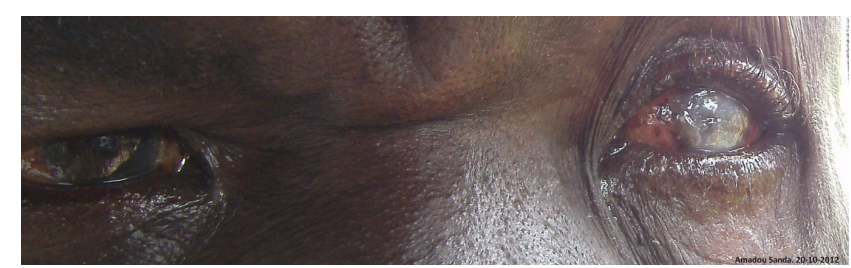

Figure 7: Keratitis ossifying of male 59 years old (Lagaye Touboro).

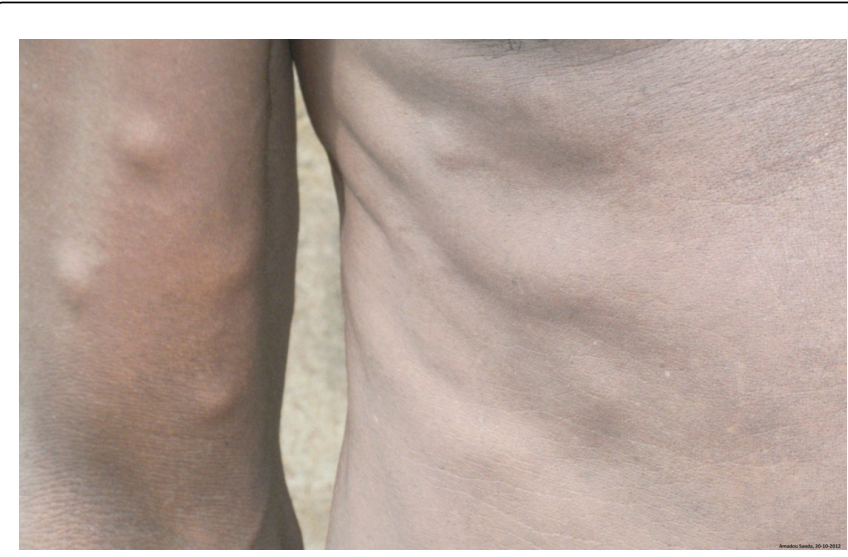

Figure 8: Nodules of male 45 years old (Lagaye -Touboro).

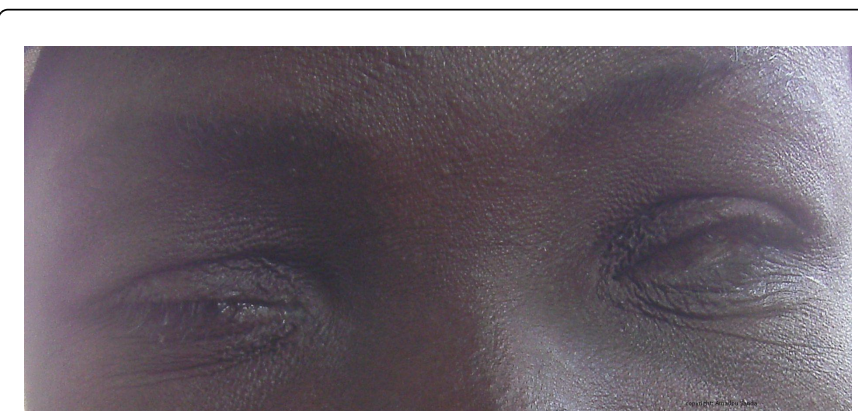

Figure 9: Blindness of the female 29 years old (LagayeTouboro).

This showed that the blackflies were more infested in Touboro than those of Wakwa. Thus the breeding of cattle in Touboro does not dilute enough aggressiveness of blackflies against human [18]. The study of graphics (Tables 8 and 9, Figures 11 and 12) increase through August to December (e.g.: 44 parous to $159 ; 5$ parasites to 3 ).

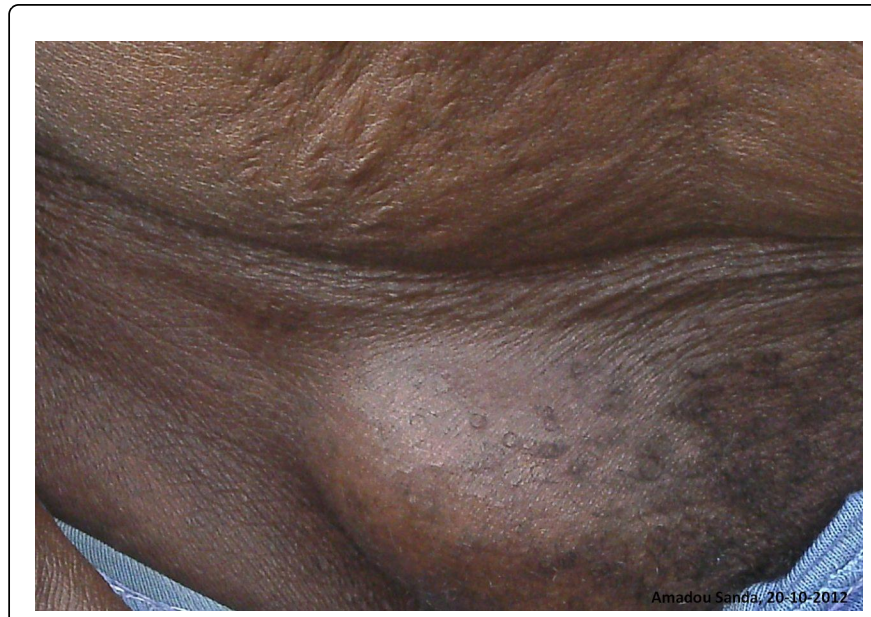

Figure 10: Hanging groin of the female 59 year old (Lagaye Touboro).

\begin{tabular}{|l|l|l|}
\hline Disected & Parous & Parasites \\
\hline 57 & 44 & 5 \\
\hline 72 & 35 & 9 \\
\hline 111 & 90 & 10 \\
\hline 113 & 73 & 23 \\
\hline 116 & 99 & 7 \\
\hline 191 & 157 & 20 \\
\hline 193 & 88 & 20 \\
\hline 216 & 159 & 53 \\
\hline
\end{tabular}

Table 8: Link between dissected, parous and parasites.

\begin{tabular}{|l|l|l|}
\hline Parous & O.volvulus & O.ochengi \\
\hline 35 & 2 & 7 \\
\hline 44 & 0 & 5 \\
\hline 73 & 3 & 20 \\
\hline 88 & 11 & 9 \\
\hline 90 & 2 & 8 \\
\hline 99 & 0 & 7 \\
\hline 157 & 6 & 14 \\
\hline 159 & 4 & 49 \\
\hline
\end{tabular}

Table 9: Link between O.volvulus and O.ochengi. 


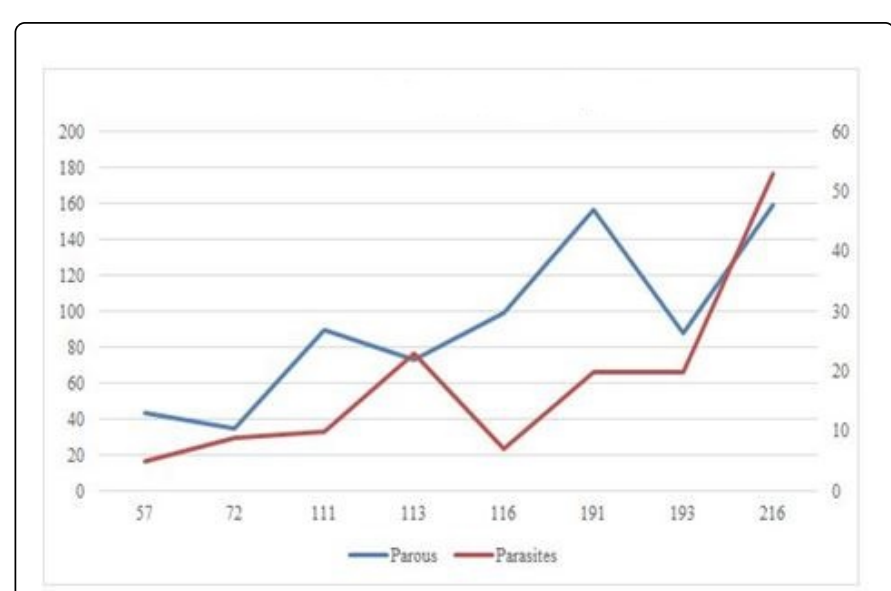

Figure 11: Trendline between dissected, parous and parasites.

The climate of Adamawa provides a framework for the cattle breeding of 1.9 million heads having been registered in connection with vaccination against 5.6 million cattle that account Cameroon. The North Region of the country has vaccinated 779.000 heads over all the cattle in the country $[19,20]$. Adamawa represents $74.51 \%$ of the cattle produced by the two Regions while the North Region has $25.50 \%$. Adamawa cattle represent 3 times the North Region's production. In the Department of Vina, there is 2.55 million heads of cattle. This is evidence that would explain the differences of infestation in the two regions of Cameroon [21].

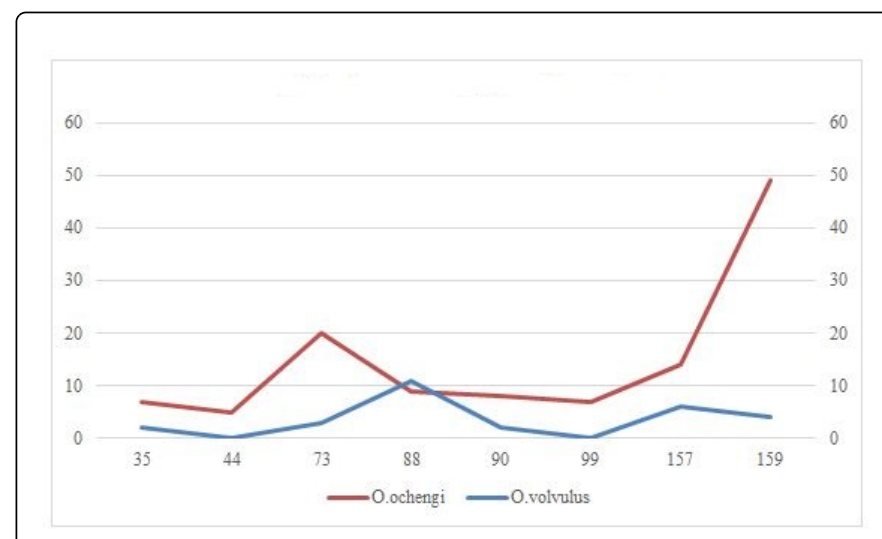

Figure 12: Trendline between $O$. volvulus and $O$. ochengi.

The climate of Adamawa provides a framework for the cattle breeding of 1.9 million heads having been registered in connection with vaccination against 5.6 million cattle that account Cameroon. The North Region of the country has vaccinated 779.000 heads over all the cattle in the country $[19,20]$. Adamawa represents $74.51 \%$ of the cattle produced by the two Regions while the North Region has $25.50 \%$. Adamawa cattle represent 3 times the North Region's production. In the Department of Vina, there is 2.55 million heads of cattle. This is evidence that would explain the differences of infestation in the two regions of Cameroon [21].

We can state that the cattle are a limiting factor of blackfly infestation by $O$. volvulus responsible for human onchocerciasis. That is why in the Northern Region. Ocular and dermal manifestations are more pronounced than in Adamawa. Livestock farming therefore play a very important role in the control of human onchocerciasis. This corroborates with Fréderic Paris [22] who stated that "the incidence of the disease is almost zero among the Bororo pastoralists while the areas of transhumance herds have a protective effect due to the bovine herd. But beyond a ratio of 4 oxen per man there is cancellation of the anthropophile preference and even dilution of bites in herds".

\section{Conclusion}

This study showed that the rates of infected blackflies by Onchocerca varied between the two zones and $O$. volvulus is more common in Touboro (Nord) than in Wakwa (Adamawa). Thus livestock also influence among other factors the prevalence of human onchocerciasis in both regions. Longitudinal studies of anthropophagic blackflies activity should be done in combination with entomological and parasitological study in 10 Regions of Cameroon.

\section{References}

1. Akpan SS, Alaribe AAA, Ejezie GC (2012) The distribution of black flies (Simulium Species) in Ugbem and Ukwepeyiere communities of biase local government area of cross river state, Nigeria. J Den Med Sci 1: 24-28.

2. Post RJ, Onyenwe E, Somiari SAE, Mafuyai HB, Crainey JL, et al. (2011) Review: A guide to the Simulium damnosum complex (Diptera: Simuliidae) in Nigeria. With a cytotaxonomic key for the identification of the sibling species. Ann Trop Med Parasitol 105: 277-297.

3. Morales H, Cheke RA, Post RJ (2006) Molecular systematics of five Onchocerca species (Nematoda: Filarioidea) including the human parasite. O. volvulus. suggest sympatric speciation. J Helminthol 80: $281-290$.

4. Sufi DA, Tukur Z (2015) Evaluation of Onchocerciasis: A decade of post treatment with ivermectin in zainabi and ririwai doguwa local government area of Kano State. Adv Entomol 3: 1-5.

5. Katabarwa MN, Lakwo T, Habomugisha P, Agunyo S, Byamukama E, et al. (2013) Transmission of Onchocerca volvulus continues in nyagakbondo focus of northwestern uganda after 18 years of a single dose of annual treatment with ivermectin. Am J Trop Med Hyg 89: 293-300.

6. Schwartz EC, Huss R, Hopkins A, Dadjim B, Madjitoloum P, et al. (1997) Blindness and visual impairment in a region endemic for onchocerciasis in the Central African Republic. Br J Ophthalmol 81: 443-447.

7. Whitcher JP, Srinivasan M, Upadhyay MP (2001) Corneal blindness: a global perspective. Bull World Health Organ 79: 214-221.

8. World Health Organazation (2001) Certification of elimination of human onchocerciasis. Criteria for certification of interruption of transmission/ elimination human onchocerciasis, Geneva, Switzerland.

9. Convit J, Schuler H, Borges R, Vimerca O, Domínguez A, et al. (2013) Interruption of Onchocerca volvulus transmission in Northern Venezuela. Parasites Vectors 6: 289-301.

10. Luyasu V, Guido K (2011) Ocular onchocerciasis: A major discovery of Jean Hissette in Central Africa. Louvain Medical 130: 387-392.

11. Post RJ, Mustapha M, Krueger (2007) A Taxonomy and inventory of the cytospecies and cytotypes Simulium damnosum complex of the (Diptera: Simuliidae) in relation to onchocerciasis Trop Med Int Health 12: 1342-1353.

12. Deffo V, Pamo ET, Tchotsoua M, Lieugomg M, Arene CJ, et al. (2011) Determination of the critical period for cattle farming in Cameroon. Int J Livestock Prod 2: 59-68.

13. Deffo V, Pamo ET, Tchotsoua N, Lieugomg M. Arene CJ, et al. (2010) Determination of the best forage production period for cattle farming in the Adamawa Region of Cameroon. Int J Biol Chem Sci 4: 130-144. 
Citation: Sanda A, Yinyang Danga SP, Youmbi N (2018) Impact of Livestock Farming on Human Onchocerciasis in Adamawa and North Regions Cameroon. J Trop Dis 6: 278. doi:10.4172/2329-891X.1000278

Page 8 of 8

14. Labonne M, Magrong P, Oustalet Y (2003) Livestock sector in Cameroon and in the provinces of the Far North: current situation. constraints. issues and challenges. Proceedings of the conference Garoua, Cameroon.

15. Bakala B (1983) Infestation by Onchocerca volvulus (Leuckart, 1893) of the Simulium damnosum complex in the region of Bunyakiri-Walikale (Kivu, Zaire). Ann Soc Belg Med Trop 63: 159-65.

16. Epidemiology of onchocerciasis: report of a WHO expert committee (1976) Geneva.

17. Regnier J C. Table from the function. Chi square.

18. Traoré S, Diarrassouba S, Hébrard G, Rivière F (1997) Natural vector capacity level of Simulium damnosum s.1. (Diptera: Simuliidae) at the ecology station of Tai (Ivory Coast). Bull Soc Pathol Exot 90: 196-199.
19. Moumini (1998) Evolution and current situation of livestock in Cameroon.

20. Boutrais J (1974) The natural conditions of livestock on the Adamawa Plateau (Cameroon) ORSTOM 11: 145-198.

21. Martínez-de la PJ, Merino S, Tomás G, Moreno J (2009). Factors affecting Culicoides species composition and abundance in avian nests. Parasitology 136: 1033-1041.

22. María EG, María GB, Sarai VM, Nestor V, Hortensia F (2001) Human onchocerciasis in the amazonian area of southern venezuela: spatial and temporal variations in biting and parity rates of black fly (Diptera: Simuliidae) Vectors. J Med Entomology 38: 520-530. 